\title{
Influence of Lherzolite on the Growth of Chinese Spinach and Soil Respiration in Cadmium Contaminated Soil
}

\author{
Ms. Misja Mumthaj Abul Muhseen1, Md. Abul Kashem,2, Md. Shoffikul Islam², \\ A. K. M. Moniruzzaman Mollah ${ }^{{ }^{*}}$ \\ ${ }^{1}$ Asian University for Women, Chittagong, Bangladesh \\ ${ }^{2}$ Department of Soil Science, Chittagong University, Chittagong, Bangladesh \\ Email: *moniruzzaman.mollah@auw.edu.bd
}

How to cite this paper: Abul Muhseen, M.M.M., Kashem, M.A. Islam, M.S., and Mollah, A.K.M.M. (2018) Influence of Lherzolite on the Growth of Chinese Spinach and Soil Respiration in Cadmium Contaminated Soil. Journal of Environmental Protection, 9, 790-800.

https://doi.org/10.4236/jep.2018.97049

Received: May 15, 2018

Accepted: June 26, 2018

Published: June 29, 2018

Copyright $\odot 2018$ by authors and Scientific Research Publishing Inc. This work is licensed under the Creative Commons Attribution International License (CC BY 4.0).

http://creativecommons.org/licenses/by/4.0/

\begin{abstract}
A glasshouse pot experiment was conducted to investigate cadmium (Cd) tolerance on the growth of Chinese spinach (Spinacia Oleracea L.) grown in sandy loam soil and microbial respiration after application of lherzolite $(0 \%$, $2.5 \%$ and $5 \%)$ with added $\mathrm{Cd}\left(0,2.5\right.$ and $\left.5 \mathrm{mg} \cdot \mathrm{kg}^{-1}\right)$. Soil $\mathrm{pH}$ tended to increase with increasing application rate of lherzolite about 1.5 units after plant harvest. Plant growth and microbial respiration in one hand decreased with the rates of $\mathrm{Cd}$ application in soil but on the other hand lherzolite application in soil reduced Cd toxicity and enhanced plant growth and microbial respiration. Microbial respiration of soil showed significant positive relationship with shoot and root dry weight of spinach but negative relationship of Cd concentration in plant tissue. This result indicated that application of lherzolite detoxified Cd toxicity in plant resulted in an increase plant growth and microbial respiration in Cd contaminated soil.
\end{abstract}

\section{Keywords}

Lherzolite, Cd, Chinese Spinach, Soil Respiration, Contamination

\section{Introduction}

Various industrial activities, manufacturing, and intensive agriculture have greatly increased the heavy metal contamination of soils over the past century. Cadmium contamination in soils has become a major environmental issue worldwide because $\mathrm{Cd}$ is ubiquitous in the human environment and has been identified as one of the most deleterious heavy metal pollutant [1]. Cadmium 
may easily transfer from soil to food plants through root systems and accumulate in the plant tissues. In this pathway, Cd may enter the food chain and affect human health [2]. Among the heavy metals in polluted soil, Cd is potentially harmful not only on humans and animals, but also on microbial activity which plays important role in maintaining soil fertility [3] [4].

Various techniques have been used for the restoration of soils contaminated with heavy metals. Current technologies for soil remediation are time consuming or too expensive. Therefore, it is important to develop techniques that can treat and stabilize heavy metals in situ in an effective and cost-effective manner [5]. It is therefore, important to find out suitable additives to immobilize Cd in soil. Several additives have been screened for their potential to immobilize heavy metals in soils [6]. Each additive has a different effect on the bioavailability of metals, micronutrient availability, soil $\mathrm{pH}$, and soil microstructure [7]. Liming can lead to significant decrease in soil solution concentration and DTPA or EDTA extractable Cd in soils amended with calcium carbonate [8].

Alkaline additives reduce heavy metal solubility in the soil by increasing soil $\mathrm{pH}$ and concomitantly increasing metal sorption to soil particles [9] [10]. Soil $\mathrm{pH}$ is one of the main parameters controlling the solubility and mobility of heavy metals in soils [11]. Agricultural liming materials, such as $\mathrm{CaCO}_{3}$, increase soil $\mathrm{pH}$ and thereby affect the activity and composition of microbial populations [12]. Microbial and chemical responses to lime vary with soiltype and management. In acid soils, liming can create better environmental conditions for the development of acid-intolerant microorganisms resulting in increased microbial biomass and soil respiration [13]. Shah et al. [14] showed a 20-fold increase in bacterial numbers after the application of $7.5 \mathrm{Mg} \cdot \mathrm{ha}^{-1}$ of ground limestone to an acidic podzolic soil.

Lherzolite [15] in powder form, is commercially available and is mined in Toono, Iwate Prefecture, Japan by the Miyamori Saiseki Co. Ltd., Japan. This material is mostly used as a raw material for concrete for making road in Japan, but in addition, this product is also used as a raw material of $\mathrm{Mg}$ fertilizer. Lherzolite is a mixture of $\mathrm{SiO}_{2}(38.5 \%), \mathrm{CaO}(2.6 \%), \mathrm{MgO}(36 \%), \mathrm{Fe}_{2} \mathrm{O}_{3}(5.9 \%), \mathrm{Al}_{2} \mathrm{O}_{3}$ $(1.9 \%)$, and $\mathrm{Ni}(0.17 \%)$ and has a $\mathrm{pH}$ 9.0. We hypothesized that this material may be useful to reduce the bioavailability and enhance plant growth and soil respiration. Therefore, the aim of this study was to assess the effect of lherzolite on the bioavailability of $\mathrm{Cd}$ to Chinese spinach and soil respiration.

\section{Materials and Methods}

\subsection{Pot Experiment}

A pot experiment was carried out in the roof top of a building of Asian University for women in Chittagong, Bangladesh. A sandy loam surface soil $(0-15 \mathrm{~cm})$ was used for this experiment. Soil sample was air dried and passed through a 4-mm sieve for using in the pots for plant growth. A sub sample was air dried and passed through a 2-mm sieve and stored for laboratory analysis. Physical and chemical properties of the soil are presented in Table 1 . Soil $\mathrm{pH}$ was meas- 
ured at 1:2.5 soil to water ratio, soil organic carbon was measured by Walkley and Black [16] and cation exchange capacity (CEC) was measured with $1 \mathrm{M}$ $\mathrm{NH}_{4} \mathrm{OAc}$ extraction [17]. The hydrometer method [18] was used for the particle size distribution. The available $\mathrm{Fe}, \mathrm{Mn}, \mathrm{Zn}, \mathrm{Cu}$ and $\mathrm{Cd}$ contents of soil were extracted by 0.005M DTPA [19] and measured by atomic absorption spectrophotometer 240 AA (Agilent Technologies, Australia) (Table 1).

Moist soil equivalent to $2 \mathrm{~kg}$ dry mass was placed in plastic pot $(20 \mathrm{~cm}$ height and $15 \mathrm{~cm}$ diameter) after mixing with $\mathrm{Cd}$ at levels of $0,2.5,5 \mathrm{mg} \cdot \mathrm{kg}^{-1}$ and lherzolite at levels of $0 \%, 2.5 \%$ and $5 \%$ on dry weight basis and their combinations. The source of $\mathrm{Cd}$ was $\mathrm{CdSO}_{4}$ (ACS grade, Sigma-Aldrich Co.) The lherzolite used in this experiment was collected from the Laboratory of Plant Physiology and Nutrition, Faculty of Agriculture, Iwate University, Japan. Each pot received a uniform basal dose of NPK fertilizer (N-P-K $=137-32-70 \mathrm{~kg} \cdot \mathrm{ha}^{-1}$ as recommended by Soil Resources Development Institute, Bangladesh [20]. The pots were arranged in a completely randomized design (CRD) with three replications.

Six seeds of Chinese spinach (Spinacia Oleracea L.) were sown in each pot and water was applied to field capacity. After 12 days of emergence, 3 healthy seedlings were kept in each pot. The plants were harvested at 45 days of growth and separated into shoot and roots. The plant parts were dried at room temperature to remove excess water prior to oven dry at $65^{\circ} \mathrm{C}$ for $72 \mathrm{~h}$ and dry mass was recorded. Plant samples were digested with nitric-perchloric acid mixtures (3:1) [21] and the Cd concentration in the digested solutions was analyzed using atomic absorption spectrophotometer 240 AA (Agilent Technologies, Australia). Reagent blanks were also processed. All results are presented on dry weight (DW) basis.

Table 1. Physical and chemical properties of the soil used in the experiment.

\begin{tabular}{|c|c|c|}
\hline \multicolumn{2}{|c|}{ Physical properties } & Values \\
\hline \multicolumn{2}{|c|}{ Moisture content (\%) } & 7.81 \\
\hline \multicolumn{2}{|c|}{ Water holding capacity (\%) } & 44.5 \\
\hline \multirow{3}{*}{ Particle size distribution (\%) } & Sand & 74 \\
\hline & Silt & 12 \\
\hline & Clay & 14 \\
\hline \multicolumn{2}{|l|}{ Textural class } & Sandy Loam \\
\hline \multicolumn{3}{|c|}{ Chemical properties } \\
\hline \multicolumn{2}{|c|}{ Organic carbon (\%) } & 0.78 \\
\hline \multicolumn{2}{|c|}{ Organic matter (\%) } & 1.17 \\
\hline \multicolumn{2}{|c|}{ Cation Exchange Capacity ( $\mathrm{cmol} \cdot \mathrm{kg}^{-1}$ soil) } & 4.39 \\
\hline \multicolumn{2}{|l|}{$\mathrm{pH}$} & 5.32 \\
\hline \multicolumn{2}{|c|}{ Available Olsen P (mg.kg $\left.{ }^{-1}\right)$} & 3.21 \\
\hline \multicolumn{2}{|l|}{$\mathrm{Fe}\left(\mathrm{mg} \cdot \mathrm{kg}^{-1}\right)$} & 92 \\
\hline \multicolumn{2}{|l|}{$\operatorname{Mn}\left(\mathrm{mg} \cdot \mathrm{kg}^{-1}\right)$} & 25 \\
\hline \multicolumn{2}{|l|}{$\mathrm{Zn}\left(\mathrm{mg} \cdot \mathrm{kg}^{-1}\right)$} & 1.6 \\
\hline \multicolumn{2}{|l|}{$\mathrm{Cu}\left(\mathrm{mg} \cdot \mathrm{kg}^{-1}\right)$} & 1.8 \\
\hline \multicolumn{2}{|l|}{$\mathrm{Cd}\left(\mathrm{mg} \cdot \mathrm{kg}^{-1}\right)$} & Below the detection limit $(<0.003)$ \\
\hline
\end{tabular}


After the harvest, soil samples were collected from each pot, air-dried, and ground to pass a $2-\mathrm{mm}$ sieve. Soil $\mathrm{pH}$ was measured the same way as mentioned above. The same soil was used to measure microbial activity or Basal respiration. The most widely used technique to quantify microbial activity is the evaluation of soil basal respiration. Soil respiration was measured by trapping the $\mathrm{CO}_{2}$ evolved from the soil during incubation period (11 days) in a closed system [22]. For this purpose, $100 \mathrm{~g}$ (oven dry basis) soil at $50 \%$ of water holding capacity (optimum moisture content for microbial activity) was placed in 1 litre capacity incubation jars and then $20 \mathrm{ml}$ of $0.5 \mathrm{M} \mathrm{NaOH}$ in $100 \mathrm{ml}$ capacity beakers were placed in each jar to trap the evolved $\mathrm{CO}_{2}$. Three jars with $0.5 \mathrm{M} \mathrm{NaOH}$ without soil were used as control. Incubation of all jars was kept at room temperature $\left(25^{\circ} \mathrm{C}\right)$. Carbon dioxide absorbed in $0.5 \mathrm{M} \mathrm{NaOH}$ after 11 was analysed. The trapped $\mathrm{CO}_{2}$ was determined by measuring electrical conductivity (EC) of the $\mathrm{NaOH}$ traps were measured and $\mathrm{CO}_{2}$ absorbance was analysed by calibration curve.

\subsection{Statistical Analysis}

Microsoft Excel and Minitab program [23] were used for analysis of variance (ANOVA).

\section{Results}

\subsection{Growth of Spinach}

The growth of spinach was significantly affected by application of lherzolite and cadmium. The height of the plant after 45 days of growth in the control pot (without Cadmium and without lherzolite application) was $29.5 \mathrm{~cm}$. The height of plant increased significantly $(\mathrm{p}<0.05)$ with the application of lherzolite at both $2.5 \%$ and $5 \%$ levels compared to the application of Cd at $5 \mathrm{mg} \cdot \mathrm{kg}^{-1}$ level (Figure 1(a)).

The shoot dry weight was the highest in the control pot (without $\mathrm{Cd}$ and lherzolite) and was the lowest in $5 \mathrm{mg} \cdot \mathrm{kg}^{-1} \mathrm{Cd}$ treated pot (without lherzolite). Dry weight of shoot increased gradually with the increase of the doses of lherzolite with and without $\mathrm{Cd}$ application in soil. Dry weight of shoots of spinach decreased from $3.33 \mathrm{~g} \cdot \operatorname{pot}^{-1}$ in control pot (without Cd) to $0.25 \mathrm{~g} \cdot \operatorname{pot}^{-1}$ with the application of $5 \mathrm{mg} \cdot \mathrm{kg}^{-1} \mathrm{Cd}$. Shoot dry weight in the pot of $5 \mathrm{mg} \cdot \mathrm{kg}^{-1} \mathrm{Cd}(0.25 \mathrm{~g})$ increased $(1.67 \mathrm{~g})$ by 7 folds with the application of $5 \%$ lherzolite in the same 5 $\mathrm{mg} \cdot \mathrm{kg}^{-1} \mathrm{Cd}$ treated pot. Application of $5 \mathrm{mg} \cdot \mathrm{kg}^{-1} \mathrm{Cd}$ decreased dry weight of shoot by 13 folds but $55 \%$ of its reduction was recovered by the application of $5 \%$ lherzolite compared to control indicating further cultivation of plants will increase the efficiency of growth enhancement and decrease Cd tolerance to plants (Figure 1(b)). Dry weight of shoots of Chinese spinach was negatively correlated $(-0.874, \mathrm{p}<0.001)$ with the concentration of $\mathrm{Cd}$ of the shoots.

Like shoot dry weight, root dry weight was influenced by lherzolite and Cd application. Lherzolite enhanced root growth both in $\mathrm{Cd}$ treated and untreated 


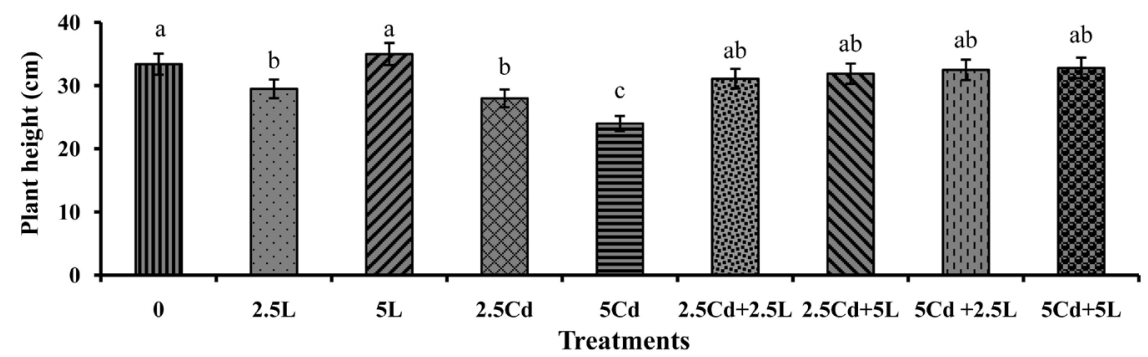

(a)

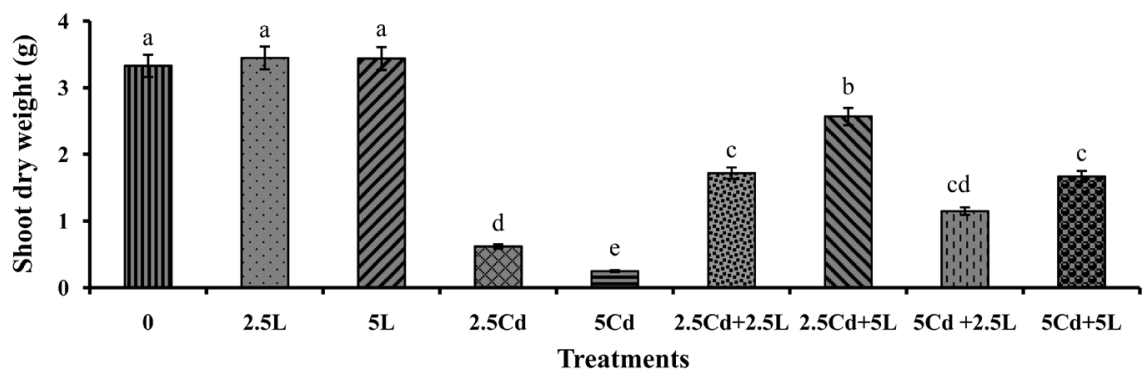

(b)

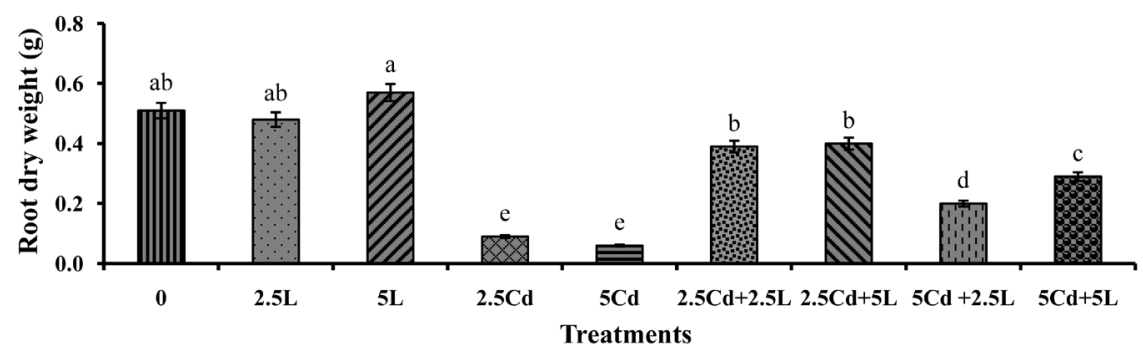

(c)

Figure 1. Growth parameters of Chinese spinach; (a) Height of the plants; (b) Dry weight of shoots and (c) Dry weight of roots. Vertical bar represent standard deviation of the three replicates. Bars with the same letters among the treatments are not significantly different from each other at $\mathrm{p}<0.05 .2 .5 \mathrm{~L}$ and $5 \mathrm{~L}$ denote 2.5 and $5 \%$ lherzolite; $2.5 \mathrm{Cd}$ and $5 \mathrm{Cd}$ denote 2.5 and $5 \mathrm{mg} \cdot \mathrm{kg}^{-1} \mathrm{Cd}$.

soil as did for shoot growth. Root dry weight decreased from $0.51 \mathrm{~g}$ in control pot (without $\mathrm{Cd}$ and lherzolite) to $0.06 \mathrm{~g}$ in $5 \mathrm{mg} \cdot \mathrm{kg}^{-1} \mathrm{Cd}$ added pot. In one hand, Cd application decreased root growth. On the other hand, it increased gradually with the application of lherzolite. Application of 5\% lherzolite increased root dry weight ( $0.06 \mathrm{~g}$ to $0.29 \mathrm{~g}$ ) by 4 folds in $5 \mathrm{mg} \cdot \mathrm{kg}^{-1} \mathrm{Cd}$ treated pot which indicates reduction of $\mathrm{Cd}$ toxic effect and enhanced root growth (Figure $1(\mathrm{c}))$.

\subsection{Cadmium Concentration in Shoots of Chinese Spinach}

Cadmium concentration was measured only in the shoots of Chinese spinach because less amount of dry matter of roots to digest. Plants grown in the control (0\%) and lherzolite (2.5\% and 5\%) amended soil without Cd addition, concentration of $\mathrm{Cd}$ was below the detection limit indicating no $\mathrm{Cd}$ was added from the amendments of lherzolite as contaminates. Shoot $\mathrm{Cd}$ concentration was the 
highest of $301 \mathrm{mg} \cdot \mathrm{kg}^{-1}$ in the plants grown in $5 \mathrm{mg} \cdot \mathrm{kg}^{-1} \mathrm{Cd}$ treated soil pot and of $101 \mathrm{mg} \cdot \mathrm{kg}^{-1}$ in the plants grown in $5 \mathrm{mg} \cdot \mathrm{kg}^{-1} \mathrm{Cd}$ treated soil amended with $5 \%$ lherzolite that resulted 3 folds (70\%) reduction of Cd uptake in shoots of Chinese spinach due to lherzolite addition. Concentration of $\mathrm{Cd}$ decreased from $191 \mathrm{mg} \cdot \mathrm{kg}^{-1}$ to $73 \mathrm{mg} \cdot \mathrm{kg}^{-1}$ when $5 \%$ lherzolite was added in the $2.5 \mathrm{mg} \cdot \mathrm{kg}^{-1} \mathrm{Cd}$ treated pot indicates higher reduction of $\mathrm{Cd}$ uptake due to lherzolite application (Figure 2).

\subsection{Soil pH}

Soil $\mathrm{pH}$ measured after the plant harvest, $\mathrm{pH}$ in the control soils was 4.4. Soil $\mathrm{pH}$ increased with the rates of lherzolite up to 5.92. In the 5\% lherzolite application pot, soil $\mathrm{pH}$ was about 1.5 units higher than the control pot. Soil $\mathrm{pH}$ showed significant negative relationship $(\mathrm{p}<0.05)$ with shoot $\mathrm{Cd}$ concentration and positive relationships with $\mathrm{CO}_{2}$ respiration and shoot dry weight (Figure 3).

\section{4. $\mathrm{CO}_{2}$-C Respiration}

Similar to shoot and root dry weights of spinach, $\mathrm{CO}_{2}-\mathrm{C}$ respiration was influenced negatively by doses of $\mathrm{Cd}$ and positively by the application of lherzolite. During the first day of incubation, $\mathrm{CO}_{2}-\mathrm{C}$ respiration increased with the rate of lherzolite in Cd contaminated soil. The rate effect of lherzolite was negligible in the $\mathrm{Cd}$ non contaminated soil. The $\mathrm{CO}_{2}-\mathrm{C}$ respiration decreased from $60 \mathrm{mg} \cdot \mathrm{kg}^{-1}$ (in the control) to $20 \mathrm{mg} \cdot \mathrm{kg}^{-1}$ (5 $\mathrm{mg} \cdot \mathrm{kg}^{-1} \mathrm{Cd}$ treated pot) soil per day. Highest dose (5\%) of lherzolite in $5 \mathrm{mg} \cdot \mathrm{kg}^{-1} \mathrm{Cd}\left(49 \mathrm{mg} \cdot \mathrm{kg}^{-1}\right.$ soil per day) treated soil increased $\mathrm{CO}_{2}-\mathrm{C}$ respiration by 2.5 folds compared to $5 \mathrm{mg} \cdot \mathrm{kg}^{-1} \mathrm{Cd}$ treated soil without lherzolite application (Figure 4).

\section{Discussion}

In the lherzolite amended soils, $\mathrm{pH}$ of the soils increased. This increase of soil $\mathrm{pH}$ in lherzolite amended soil will lead to reduction of Cd bioavailable in soil. The chemical composition of lherzolite may cause to either fixation of $\mathrm{Cd}$ by

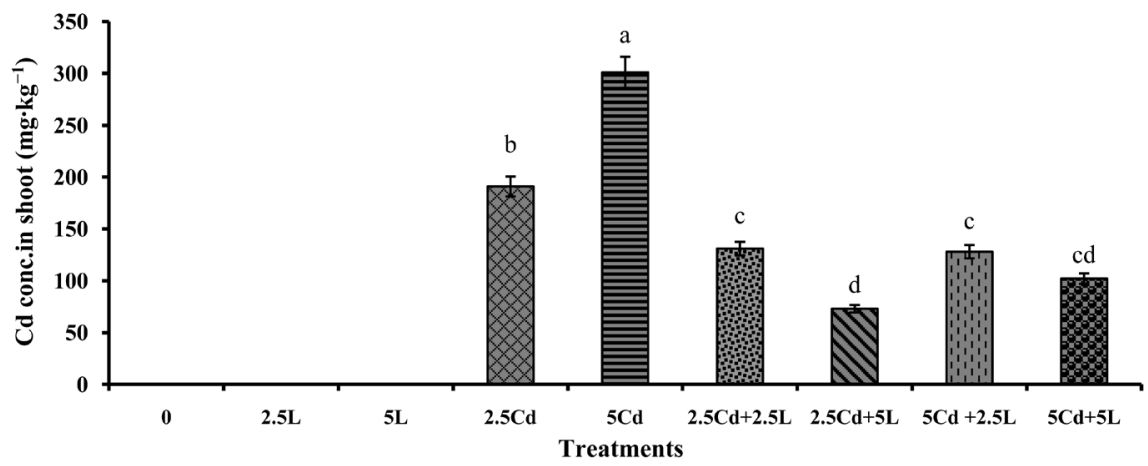

Figure 2. Cadmium concentration in the shoots of Chinese spinach. Vertical bar represent standard deviation of the three replicates. Bars with the same letters among the treatments are not significantly different from each other at $\mathrm{p}<0.05 .2 .5 \mathrm{~L}$ and $5 \mathrm{~L}$ denote $2.5 \%$ and $5 \%$ lherzolite; $2.5 \mathrm{Cd}$ and $5 \mathrm{Cd}$ denote 2.5 and $5 \mathrm{mg} \cdot \mathrm{kg}^{-1} \mathrm{Cd}$. 


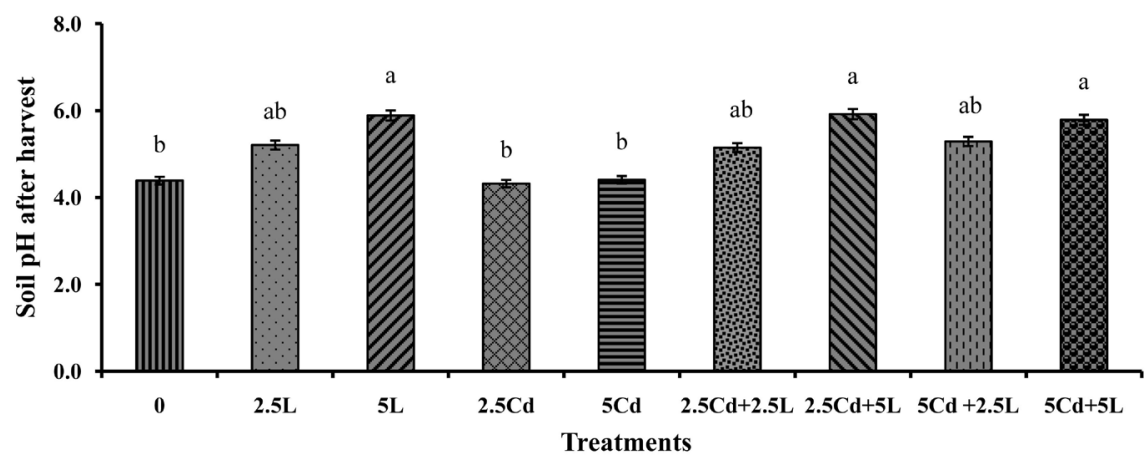

Figure 3. Soil pH after harvest of Chinese spinach. Vertical bar represent standard deviation of the three replicates. Bars with the same letters among the treatments are not significantly different from each other at $\mathrm{p}<0.05 .2 .5 \mathrm{~L}$ and $5 \mathrm{~L}$ denote $2.5 \%$ and $5 \%$ lherzolite; $2.5 \mathrm{Cd}$ and $5 \mathrm{Cd}$ denote 2.5 and $5 \mathrm{mg} \cdot \mathrm{kg}^{-1} \mathrm{Cd}$.

providing large surface areas or to precipitation of this metal. The use of $\mathrm{Ca}$ and $\mathrm{Mg}$ carbonates and $\mathrm{Ca}$ oxides [24] [25], and zeolites, bringite, and hydrous oxides of $\mathrm{Fe}, \mathrm{Al}$, and $\mathrm{Mn}$ and hydroxyapatite-like compounds derived from oyster shell [26] [27] [28] can reduce metal mobility significantly in soils and their uptake by plants.

Increasing soil $\mathrm{pH}$ was a common mechanism of action for all the amendments. Our results of $\mathrm{pH}$ increase are in accordance with those of other researchers [26] [29]. The increase of $\mathrm{pH}$ value of soil lowered the solubility of heavy metals in the soil [8] [30]. Lee et al. [8] found that soil $\mathrm{pH}$ was increased after addition of Ca carbonate and decreased significantly DTPA extractable Cd in a sandy soil. In addition, the rising of soil $\mathrm{pH}$ increased the $\mathrm{pH}$-dependent charges and also increased the metals adsorbed on soil particles [31]. In this study, lherzolite behaved like those of red mud as well as lime, beringite and hydroxyapatite-like compounds. We can speculate that the fixation mechanism (reduction of bioavailable $\mathrm{Cd}$ ) of $\mathrm{Cd}$ in the case of lherzolite could be mostly due to $\mathrm{pH}$ increase and also ion exchange and precipitation or coprecipitaion of metals [32].

It was clearly shown in this experiment that growth of Chinese spinach was greatly enhanced by lherzolite and Cd concentration in plant tissues was largely reduced. The reduced bioavailability of $\mathrm{Cd}$ by amendment with lherzolite may be chiefly a consequence of $\mathrm{pH}$ rise. This increase of soil $\mathrm{pH}$ in the soil amended with lherzolite reduced the phytotoxicity of $\mathrm{Cd}$, resulting in significantly lower Cd concentrations of shoots Chinese spinach (Figure 2 and Figure 3). The improvement Chinese spinach growth may be related with the addition of lherzolite and that could be partially explained by its detoxifying effect of $\mathrm{Cd}$ in the soil by other nutrients ( $\mathrm{Si}, \mathrm{Ca}$, and $\mathrm{Mg}$ ) derived from lherzolite. Besides $\mathrm{Ca}$ and $\mathrm{Mg}$, essential nutrients, Sihas also been shown to have a beneficial role in plant

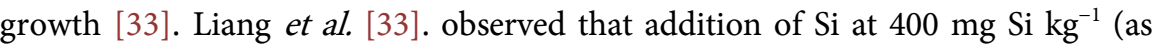
$\mathrm{Na}_{2} \mathrm{SiO}_{3} \cdot 9 \mathrm{H}_{2} \mathrm{O}$ ) increased soil $\mathrm{pH}$, decreased Cd availability in soil, and thus reduced $\mathrm{Cd}$ concentration in plant. Kashem and Kawai [34] found that Cd 


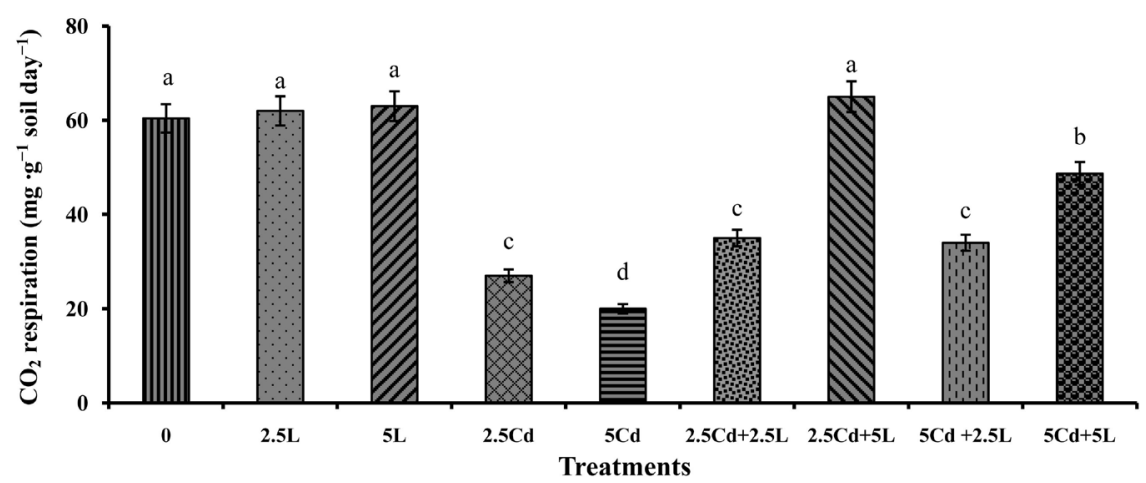

Figure 4. $\mathrm{CO}_{2}-\mathrm{C}$ respiration of soils after harvest of Chinese spinach. Vertical bar represent standard deviation of the three replicates. Bars with the same letters among the treatments are not significantly different from each other at $\mathrm{p}<0.05 .2 .5 \mathrm{~L}$ and $5 \mathrm{~L}$ denote $2.5 \%$ and $5 \%$ lherzolite; $2.5 \mathrm{Cd}$ and $5 \mathrm{Cd}$ denote 2.5 and $5 \mathrm{mg} \cdot \mathrm{kg}^{-1} \mathrm{Cd}$.

concentration in the shoots of Japanese Mustard spinach was reduced by $40 \%$ when this crop was grown under 10-fold concentration of $\mathrm{Mg}$ in the hydroponics, indicating detoxifying effect of $\mathrm{Mg}$ on plant $\mathrm{Cd}$.

This study also showed that soil respiration $\left(\mathrm{CO}_{2}\right.$ evolution $)$ decreased with increasing $\mathrm{Cd}$ concentrations in soil which indicates that $\mathrm{Cd}$ has a toxic effect on microbial respiration. Similar of our result was observed by other investigators [35] [36]. Verma et al. [36] found soil respiration $\left(\mathrm{CO}_{2}\right.$ evolution) significantly decreased in Cd contaminated soils compared to uncontaminated soils. The addition of lherzolite to the soil diminished the inhibitory effects of $\mathrm{Cd}$ on biological parameters and hence enhanced soil respiration. The addition of this kind of material can help in the remediation of Cd polluted soils.

\section{Conclusion}

Cadmium is toxic to plant and on soil microbial activity. Addition of $\mathrm{Cd}$ to the soil caused to decrease plant growth and microbial respiration that can be detoxified or diminished by the application lherzolite in soil. This result indicates that lherzolite can be used to remediate Cd contaminated soil.

\section{Acknowledgements}

The senior author is grateful to the Asian University for Women, Chittagong (AUW) Bangladesh for granting research fund. The authors acknowledge Mr. Md. Mamunur Rashid ex-student of the Department of Soil Science, University of Chittagong, Bangladesh for his assistance during the experiment.

\section{References}

[1] Christine, C.C. (1997) Cadmium Bioaccumulation in Carp (Cyprinus carpio) Tissues during Long-Term High Exposure: Analysis by Inductively Coupled Plasma-Mass Spectrometry. Ecotoxicology and Environmental Safety, 38, 137-143. https://doi.org/10.1006/eesa.1997.1569

[2] Adriano, D.C. (1986) Trace Elements in the Terrestrial Environment. Springer, New 
York, 533. https://doi.org/10.1007/978-1-4757-1907-9

[3] Giller, K.E., Witter, E. and McGrath, S.P. (1998) Toxicity of Heavy Metals to Microorganisms and Microbial Processes in Agricultural Soils: A Review. Soil Biology and Biochemistry, 30, 1389-1414. https://doi.org/10.1016/S0038-0717(97)00270-8

[4] Nannipieri, P., Badalucco, L., Landi, L. and Pietramellara, G. (1997) Measurement in Assessing the Risk of Chemicals to the Soil Ecosystem. In: Zelikoff, J.T., Ed., Proceedings of the OECD Workshop on Ecotoxicology: Responses and Risk Assessment, SOS Publications, Fair Haven, 1-28.

[5] Wenzel, W.W., Adriano, D.C. and Smith, R. (1999) Phytoremediation: A Plant-Microbe-Based Remediation System. In: Hanks, J. and Ritchie, J.T. Eds., Bioremediation of Contaminated Soils, Agronomy Monograph No. 37, American Society of Agronomy, Crop Science Society of America and Soil Science Society of America, 457-508.

[6] Misra, V., Tiwari, A., Shukla, B. and Seth, C.S. (2009) Effects of Soil Amendments on the Bioavailability of Heavy Metals from Zinc Mine Tailings. Environmental Monitoring and Assessment, 155, 467-475. https://doi.org/10.1007/s10661-008-0449-5

[7] Lombi, E., Hamon, R.E., Mcgrath, S.P. and Mclaughlin M.J. (2003) Lability of Cd, $\mathrm{Cu}$ and $\mathrm{Zn}$ in Polluted Soils Treated with Lime, Beringite, and Red Mud and Identification of a Non-Labile Colloidal Fraction of Metals Using Isotopic Techniques. Environmental Science and Technology, 37, 979-984. https://doi.org/10.1021/es026083w

[8] Lee, T.M., Lai, H.Y. and Chen, Z.S. (2004) Effect of Chemical Amendments on the Concentration of Cadmium and Lead in Long-Term Contaminated Soils. Chemosphere, 57, 1459-1471. https://doi.org/10.1016/j.chemosphere.2004.08.094

[9] Puschnereiter, M.M., Horak O., Friesl W. and Hartl, W. (2005) Low-Cost Agricultural Measures to Reduce Heavy Metal Transfer into the Food Chain-A Review. Plant Soil and Environment, 51, 1-11. https://doi.org/10.17221/3549-PSE

[10] McBride, M., Sauve, S. and Hendershot, W. (1997) Solubility Control of Cu, Zn, Cd, and $\mathrm{Pb}$ in Contaminated Soils. European Journal of Soil Science, 48, 337-346. https://doi.org/10.1111/j.1365-2389.1997.tb00554.x

[11] Burgos, P., Madejon, E., Perez-Mora, A. and Cabera, F. (2006) Spatial Variability of the Chemical Characteristics of a Trace-Element-Contaminated Soil before and after Remediation. Geoderma, 130, 157-175.

https://doi.org/10.1016/j.geoderma.2005.01.016

[12] Tate, R.L. (2000) Soil Microbiology. 2nd Edition, Wiley, New York.

[13] Neale, S.P., Shah, Z. and Adams, W.A. (1997) Changes in Microbial Biomass and Nitrogen Turnover in Acidic Organic Soils Following Liming. Soil Biology and Biochemistry, 29, 1463-1474. https://doi.org/10.1016/S0038-0717(97)00040-0

[14] Shah, Z., Adams, W.A. and Haven, C.D.V. (1990) Composition and Activity of the Microbial Population in an Acidic Upland Soil and Effects of Liming. Soil Biology and Biochemistry, 22, 257-263. https://doi.org/10.1016/0038-0717(90)90095-H

[15] Liu, Y., Gao, S., Lee, C.T.A., Hu, S., Liu, X. and Yuan, H. (2005) Melt-Peridotite Interactions: Link between Garnet Pyroxenite and High-Mg Signature of Continental Crust. Earth and Planetary Science Letters, 234, 39-57. https://doi.org/10.1016/j.epsl.2005.02.034

[16] Walkley, A. and Black, I.A. (1934) An Examination of Degtjareff Method for Determining Soil Organic Matter and a Proposed Modification of the Chromic Acid 
Titration Method. Soil Science, 37, 29-38. https://doi.org/10.1097/00010694-193401000-00003

[17] Soil Survey Laboratory Staff (1992) Soil Survey Laboratory Methods Manual. Soil Survey Laboratory, Washington DC.

[18] Bouyoucos, G.J. (1962) Hydrometer Method Improved for Making Particle Size Analysis of Soils. Agronomy Journal, 54, 464-465. https://doi.org/10.2134/agronj1962.00021962005400050028x

[19] Lindsay, W.L. and Norvell, W.A. (1978) Development of DTPA Soil Test for Zinc, Iron, Manganese, and Copper. Soil Science Society of America Journal, 42, 421-428. https://doi.org/10.2136/sssaj1978.03615995004200030009x

[20] Soil Resources Development Institute (2008) Report of Land and Soil Resource Use. Upazila Report Series-29, Hathazari Upazila.

[21] Piper, C.S. (1942) Soil and Plant Analysis. Hassell Press, Adelaide.

[22] Alef, K. (1995) Estimation of Soil Respiration. In: Alef, K. and Nannipieri, P., Eds., Methods in Applied Soil Microbiology and Biochemistry, Academic Press, London, 464-467.

[23] Minitab (1996) Minitab User's Guide, Release 11. State College.

[24] Derome, J. (2000) Detoxification and Amelioration of Heavy-Metal Contaminated Forest Soils by Means of Liming and Fertilization. Environmental Pollution, 107, 79-88. https://doi.org/10.1016/S0269-7491(99)00132-3

[25] Lombi, E., Zhao, F.J., Zhang, G., Sun, B., Fitz, W., Zhang, H., et al. (2002) In Situ Fixation of Metals in Soils Using Bauxite Residue: Chemical Assessment. Environmental Pollution, 118, 435-443. https://doi.org/10.1016/S0269-7491(01)00294-9

[26] Islam, M.S., Ueno, D., Someya, T. and Inoue, K. (2012) Suppressive Effects of Hydroxyapatite-Like Compounds Added to Soil on Cadmium Uptake by Plants. Environmental Control in Biology, 50, 383-392.

[27] Castaldi, P., Santona, L. and Melis, P. (2005) Heavy Metal Immobilization by Chemical Amendments in a Polluted Soil and Influence on White Lupin Growth. Chemosphere, 60, 365-371. https://doi.org/10.1016/j.chemosphere.2004.11.098

[28] Loland, S.Q. and Singh, B.R. (2004) Extractability and Plant Uptake of Copper in Contaminated Coffee Orchard Soils as Affected by Different Amendments. Acta Agriculturae Scandinavica, Section B-Soil \& Plant Science, 54, 121-127. https://doi.org/10.1080/09064710410035640

[29] Paulose, B., Datta, S.P., Rattan, R.K. and Chhonkar, P.K. (2007) Effects of Amendments on the Extractability, Retention and Plant Uptake of Metals on a Sewage-Irrigated Soil. Environmental Pollution, 146, 19-24. https://doi.org/10.1016/j.envpol.2006.06.016

[30] Kashem, M.A. and Singh, B.R. (2001) Metal Availability in Contaminated Soils: I. Effect of Flooding and Organic Matter in Changes in Eh, $\mathrm{pH}$ and Solubility of Cd, $\mathrm{Ni}$ and Zn. Nutrient Cycling in Agroecosystems, 61, 247-255. https://doi.org/10.1023/A:1013762204510

[31] Pardo, M.T. and Guadalix, M.E. (1996) Zinc Sorption-Desorption by Two Andept: Effect of pH and Support Medium. European Journal of Soil Science, 47, 257-263. https://doi.org/10.1111/j.1365-2389.1996.tb01397.x

[32] Mench, M.J., Manceau, A., Vangronsveld, J., Clijsters, H. and Mocquot, B. (2000) Capacity of Soil Amendments in Lowering the Phytoavailability of Sludge-Borne Zinc. Agronomy, 20, 383-397. https://doi.org/10.1051/agro:2000135 
[33] Liang, Y., Wong, J.W. and Wei, L. (2005) Silicon-Mediated Enhancement of Cadmium Tolerance in Maize (Zea mays L.) Grown in Cadmium Contaminated Soil. Chemosphere, 58, 475-483. https://doi.org/10.1016/j.chemosphere.2004.09.034

[34] Kashem, M.A. and Kawai, S. (2007) Alleviation of Cadmium Phytotoxicity by Magnesium in Japanese Mustard Spinach. Soil Science and Plant Nutrition, 53, 246-251. https://doi.org/10.1111/j.1747-0765.2007.00129.x

[35] Morenoa, J.L., Hernández, T., Pérez, A. and Garcia, C. (2002) Toxicity of Cadmium to Soil Microbial Activity: Effect of Sewage Sludge Addition to Soil on the Ecological Dose. Applied Soil Ecology, 21, 149-158. https://doi.org/10.1016/S0929-1393(02)00064-1

[36] Verma, R.K., Yadav, D.V., Singh, C.P., Suman, A. and Gaur, A. (2010) Effect of Heavy Metals on Soil Respiration during Decomposition of Sugarcane (Saccharum officinarum L.) Trash in Different Soils. Plant Soil and Environment, 56, 76-81. https://doi.org/10.17221/1773-PSE 